\title{
The Influence of School Environment and Teacher Work Motivation on Teacher Professionalism
}

\author{
Yusnawati $^{\left.1^{*}\right)}$, Muhammad Kristiawan ${ }^{2}$, Yenny Puspita ${ }^{2}$ \\ ${ }^{1}$ SMP Negeri 12 Palembang, \\ ${ }^{2}$ University of PGRI Palembang \\ *Corresponding author.E-mail: yusnapalembang@gmail.com
}

\begin{abstract}
The research was conducted with the aim of 1) knowing and describing the influence of the school environment on teacher professionalism in SMP Negeri Kertapati District; 2) knowing and describing the effect of teacher work motivation on teacher professionalism in SMP Negeri Kertapati District, and 3) knowing the effect of the school environment and teacher work motivation on teacher professionalism in SMP Negeri Kertapati District. The type of research is quantitative research. This study concludes that 1) There is an effect of the school environment on the professionalism of teachers in SMP Negeri Kertapati District, Palembang; 2) There is an effect of teacher work motivation on teacher professionalism in SMP Negeri Kertapati District, Palembang; and 3) There is an influence of the school environment and work motivation on the professionalism of teachers in SMP Negeri Kertapati District, Palembang.
\end{abstract}

Keywords: School Environment, Teacher Work Motivation, Teacher Professionalism

\section{INTRODUCTION}

This experiment is based on the findings of several researchers in several regions in Indonesia who concluded that teacher professionalism can be affected by numerous factors, including school environment, job motivation, primary leadership, organizational culture, skills, work environment, supervision. Principals of schools, occupational allowances, etc.

Teachers must develop and enhance educational competencies and skills by carrying out professional duties to continue in the same direction as the development of science and technology and art. The ability to master content, manage the learning process, manage students, manage learning resources and materials, comply with basic education, identify learning relationships, review student performance, recognize roles and systems of counseling guidance service, and understand school administration are requirements for teacher professionalism.

Professionalism is like allows teachers to carry out their duties, all of which are affected by a variety of key factors, namely internal factors, including desires and skills, and external factors, including teachers' different exercises, the atmosphere, and facilities.

The teaching and learning process, including school leadership, structure and strategy of investigation, the existence of the workspace, air circulation, room form, room contrast, lighting, the position of doors and windows, positioning of office equipment, blackboards and chairs, and the teacher's desk, fixtures, the positioning of the seats, the arrangement of media for learning, the availability of books that can support the continuity can be supported by the work environment in the school. [1].

The learning environment is one of the factors related to personal psychological aspects, such as the type of interaction between opinions, desires, and happiness that usually happens in a personality. This same instinct of someone is an urge to meet needs that are material in character. Motivation is the motivating force for people to do work to fulfill many needs or wishes at various levels. Employee productivity is the situation and energy that drives a person who is organized and directed to achieve and maintain an agency's goals. A good person's psychological perspective on the work role is required to increase work motivation to achieve optimal performance [2].

This research was performed in Kertapati District, Palembang, at the State Junior High School. It is interesting for this school to be a place of study with several considerations, namely, 1) News Portal Public Reports 26 November 2019 recommends that SMP Negeri 12 in Palembang District of Kertapati is a suburban school with A accreditation and has a strong school climate and is classified as Adiwiyata National level; 2) As a public school in Palembang Region, the school has appropriate infrastructure and facilities; 3) The school has many achievements [3].

\section{Teacher Professionalism}

Two syllables that have their meaning, namely the terms professionalism and teacher, include the expression 
teacher professionalism. The phrase professionalism detracts from the word technical, the fundamental word of which is a career. To create useful individuals in the next century, a teacher has a heavy-duty to educate his students. The human resources of a school organization are students [4]. The principal keys to smooth and effective learning are competent teachers. Since only skilled teachers in learning activities may establish an active situation for students [5]. Schools must therefore need and teach learners so that educators have a high level of professionalism in the performance of their duties, particularly in the performance of educators' main duties and functions [6]. In educational institutions, educators are pioneers, possessing the primary and most important facets of their life. Teachers with a high degree of professionalism are seen in different ways, both in terms of pedagogical, technical, and social skills [7].

It is necessary to formulate educator professionalism; the first: by understanding the provisions of the standardization of work. Second: achieving the abilities and skills required. Third: all over specialized organizations, there is a slick and responsive friendship activity. Fourth: development of ethics or work ethics that enable a good standard of service. fifth: scanning for breakthroughs and developing work in using the new communication technologies and information in their ability to handle lessons [8]

Same with Law number 14 of 2005 concerning educators and Lecturers of article 7, paragraph 1, regarding the values of professional teachers, it contains many items, namely: 1) Having the ability, desire, and being able to master teaching materials; 2) To be able to handle classes, have professional competence and educational history; 3) Have the skills that are supposed to be in line with the educational media; 4) Has a specific ethical professional code and foundation for education; 5) Responsible for the execution of professional roles in the management of learning experiences.

From a number of these statements, it can be argued that teacher professionalism is a discipline and a role that is dedicated exclusively to the education and training field. And they will still aspire to improve skills according to their career.

\section{Teacher Work Motivation}

The term motivation comes from the word motive, which can be defined as a person's desire to act and behave. Motives can not be immediately observed but can be converted into actions in the form of inspiration, encouragement, or stimulation for a certain behavior to arise [9]. Meanwhile, motivation is one of the techniques of a superior, chief, or manager to ensure that workers choose to be smart according to what they want, according to Setiyati, it can be calculated from the understanding of motivation that motivation is a motivating and driving force for someone to want to work and strive to be better [10]. Educators must have work motivation so that they are willing and willing to use all their skills in the form of abilities and expertise in carrying out their duties and duties. Thus, for the teaching and learning process to take place efficiently and produce something good, educators must develop their professionalism, and achieve this, they must be stimulated by adequate welfare and high work motivation [11]. Uno suggests that encouragement for teacher work is a tool used to inspire teachers so that teacher action can be directed at actual attempts to achieve the expected goals [9].

In the meantime, Sulthoni et. al. conclude that "As an education professional teachers have different work motivations from one teacher to another" [12]. And the motivation for work is fundamentally split into two forms, namely, the motivation that comes from outside the individual/extrinsic and within the individual/intrinsic. In motivating a teacher to make attempts to be better and more creative, these two aspects are very necessary and inversely [9]. Mangkunegara discusses measures of job motivation, namely; 1) Life needs are linked to the physical existence of teachers, such as food, clothes, salaries, beverages, allowances, and occupational safety, 2) Requires for relationships, namely a sense of work environment-related satisfaction, and 3) The need for self-development, skills development and self-potential concerning teacher skills and abilities [2].

It can be observed from the many meanings of motivation that work motivation is a movement or stimulation that lives inside the individual, either starting from himself or outside himself, to perform a job with high enthusiasm through the use of the skills and knowledge he has.

\section{School Environment}

Supardi notes that all living and inanimate objects and all conditions found in the earth we live in are known as the school climate [13]. The school environment is the whole space that includes formal education which influences the formation of behavior and increases the abilities of students [14]

The school atmosphere includes 1) the school's physical environment, including the situation and infrastructure, the infrastructure and infrastructure in learning, the materials in learning and the facilities for learning, and the infrastructure for learning; 2) The social environment, which refers to the impact of learners with their peers, teachers and other school staff; and 3) A school situation and the performance of learning programs and many extracurricular activities is an academic climate [15].

Based on these ideas, it can be inferred that the school environment is a system of a school that can influence the progression and growth of the mindsets of students, and the school environment can also be defined as all elements or components in the school, in which all elements and components play a role in helping the learning objectives of schools to succeed.

\section{METHODS}

This research is quantitative. As for what researchers mean from quantitative data, it is a study that 
can be measured directly and can be calculated [16]. The research started from initial observation in writing the background of the problem from September to November 2020 for about 3 months. This survey questionnaire consisted of 144 teachers. Although the study sample obtained as many as 59 teachers using the Solvin process.

Techniques for data collection using interviews and methods of recording. What questionnaires mean is multiple written statements used to extract information from resource persons in the context of personality reports, the methodology is carried out by providing subjects with several statements and written questions to answer [17]. Djumhur stated that records are a list of facts, such as master books, certificates, etc, recorded in written books. It also can be inferred that the method of documentation is required as a supporting researcher since it is possible to obtain school profile with this method, and data on the past of the establishment of the school, school vision and mission, teacher lists, student lists, and other documents.

\section{RESULT AND DISCUSSION}

Respondent data analysis consisted of gender, level of education, and years of service. Analysis of the reports used in this study by using the items used to assess the frequency distribution of the responses of respondents from the results of the collected questionnaires using descriptive statistical analysis. Standardized multiple regression analysis has been analyzed and the results in this study via the SPSS software to test the hypothesis. It can be seen from the distribution of the frequency of respondents' responses that the total scoring is as follows for each item under study and the average scoring for each parameter. $0.00-0.199=$ very low, $0.20-0.399=$ low, $0.40-0.599=$ moderate, $0.60-0.799=$ strong, 0.80 - $1,000=$ very strong [17].

The initial activity carried out an assessment and narrated the distribution of respondent responses for each question item before carrying out the process of testing the hypothesis.

The One-Sample Kolmogorov-Smirnov Test was used to test for normality. For each parameter, the usual testing stage is decided from the asymp sig (2-tailed) value, which must be large or equal to 0.05 alpha. Based on the data steps that have been done, it can be concluded that the results of the data normality test are described in table 1 .

Table 1. Normality Test Results from Data

\begin{tabular}{|l|l|l|}
\hline Variable & $\begin{array}{l}\text { Sig } \\
\text { Tailed }\end{array}$ & Conclusion \\
\hline school environment $\left(\mathbf{X}_{1}\right)$ & 0,200 & Normal \\
teacher work motivation $\left(\mathbf{X}_{2}\right)$ & 0,200 & Normal \\
teacher professionalism $(\mathbf{Y})$ & 0,200 & Normal \\
\hline
\end{tabular}

The table illustrates that each creates a report consisting of variables in the school environment (X1), encouragement for teacher work (X2), and professionalism of teachers (Y) has an asymp sig (2tailed) value greater than or equal to alpha 0-, 05 (Sig> $0.055)$ It also can be inferred that all the analysis factors used are normally distributed. In used to execute the next data processing stage immediately.

Table 2. Reliability Test Results from Research Instrument

\begin{tabular}{|l|l|l|}
\hline Variable & $\begin{array}{l}\text { Sig (2- } \\
\text { Tailed })\end{array}$ & Conclusion \\
\hline school environment $\left.\mathbf{X}_{1}\right)$ & 0,741 & Reliable \\
teacher work motivation $\left(\mathbf{X}_{2}\right)$ & 0,747 & Reliable \\
teacher professionalism (Y) & 0,736 & Reliable \\
\hline
\end{tabular}

The parameter for instrument reliability testing is if the alpha value of the Cronbach is > 0.6 (standard reliability value) and the instrument is determined to be reliable. However, if the alpha value of the Cronbach is less than 0.6, then the instrument with a substantial amount of 5 percent is determined not to be useful. The reliability test was tested using the SPSS version 25.0 program on a computer.

Table 3. Results of many data analysis of correlation and coefficient of determination

\begin{tabular}{|l|l|l|l|}
\hline $\mathrm{R}$ & $\begin{array}{l}\mathrm{R} \\
\text { Square }\end{array}$ & $\begin{array}{l}\text { Adjusted } \mathrm{R} \\
\text { Square }\end{array}$ & $\begin{array}{l}\text { Std. The error of the } \\
\text { Estimate }\end{array}$ \\
\hline 0,515 & 0,265 & 0,239 & 4,327 \\
\hline
\end{tabular}

The results of the report of the determination coefficient using the SPSS model summary program indicate that the magnitude of R Square is 0,265 or 26.5 percent, in this case, the component of the school environment, motivation for teacher work, to teacher professionalism while the rest is (26.5 percent-100 percent $)=73.5$ percent is affected by other variables not present for this research.

Table 4. Simultaneous analysis with ANOVA F-test data

\begin{tabular}{|l|c|l|l|l|l|}
\hline Model & $\begin{array}{l}\text { Sum of } \\
\text { Squares }\end{array}$ & df & $\begin{array}{l}\text { Mean } \\
\text { Square }\end{array}$ & F & Sig. \\
\hline Regression & 378,330 & 2 & 189,165 & 10,104 & 0,000 \\
$\begin{array}{l}\text { Residual } \\
\text { Total }\end{array}$ & 1048,382 & 56 & 18,721 & & \\
\hline
\end{tabular}

Ho is rejected from joint testing with the independent F-test variable $\left(\mathrm{X}_{1}\right)$ and $\left(\mathrm{X}_{2}\right)$ with the dependent variable $(\mathrm{Y})$ with a value of $0.000<0.05$. Accepted Ha. This shows that the school environment and reassurance for teacher work influence teacher professionalism.

\section{Table 5. The T-test Coefficients}

\begin{tabular}{|c|c|c|c|c|c|c|}
\hline & \multirow[t]{2}{*}{ Model } & \multicolumn{2}{|c|}{$\begin{array}{l}\text { Unstandardized } \\
\text { Coefficients }\end{array}$} & \multirow{2}{*}{$\begin{array}{c}\text { Standardized } \\
\text { Coefficients } \\
\text { Beta }\end{array}$} & \multirow[t]{2}{*}{$\mathrm{t}$} & \multirow[t]{2}{*}{ Sig. } \\
\hline & & B & $\begin{array}{l}\text { Std. } \\
\text { Error }\end{array}$ & & & \\
\hline 1 & $\begin{array}{l}\text { (Consta } \\
\mathrm{nt})\end{array}$ & 30,757 & 12,880 & & 2,388 & 0,020 \\
\hline & $\mathrm{X}_{1}$ & 0,277 & 0,086 & 0,390 & 3,240 & 0,002 \\
\hline & $\mathrm{X}_{2}$ & 0,389 & 0,098 & 0,476 & 4,955 & 0,000 \\
\hline
\end{tabular}

a. Dependent Variable: Y 
Table 5 is the result of the regression coefficients on teachers' professionalism (Y) for the school environment variable $\left(\mathrm{X}_{1}\right)$, which is sig $=0.002$. And the effect of the regression coefficient on teacher professionalism (Y) for the teacher job motivation variable $\left(\mathrm{X}_{2}\right)$, which is rated at $\operatorname{sig}=0.000$. The results of the test are mainly known by comparing the sig value and the sig $<0.05$ limit. So the certainty value of significance of $0.000<0.05$ means that Ho is rejected, $\mathrm{Ha}$ is approved with an error rate of 5 percent or 0.05 , and it can be inferred that there is an effect on teacher professionalism between the school climate and teacher job motivation. Based on the results of the significance test, the regression equation in this study is:

$\mathrm{Y}=31,124+0,284 \mathrm{X}_{1}+0,374 \mathrm{X}_{2}$

\section{The Effect of School Environment $\left(X_{I}\right)$}

The findings revealed that factor in the school environment has a major impact on the integrity of the variable teacher. These theories assert that variable in the school setting has a major impact on the variable of effective teaching. It can be clarified if the value of the School Environment variable $\left(\mathrm{X}_{1}\right)$ rises unit score, so the professionalism of the instructor (Y) will rise by 30,757 , 1 unit score, so that value of school environment $\left(\mathrm{X}_{1}\right)$ is fixed, per the results of formulas standard regression equation estimated regression equation refer to table 5 (coefficient) As to if the school climate $\left(\mathrm{X}_{1}\right)$ has a big impact on teacher performance $(\mathrm{Y})$, a value of $\mathrm{r}$ square can be seen in Table 5. For School Environment, the value of $\mathrm{t}_{\text {count }}$ is 3,240 with a huge value of 0,000 ( $\mathrm{p}<$ $0.05)$ with a table of 1,420 or, in other words, $t_{\text {count }}>t_{\text {table, }}$ then refusing $\mathrm{H}_{0}$ and approving $\mathrm{Ha}$ or, in other words, this indicates that the variables of the school setting have a major impact $\left(\mathrm{X}_{1}\right)$ on Professionalism for Teachers $(\mathrm{Y})$. The same thing was also discovered by Wulandari that there is an impact on the professionalism of the teachers of Madrasah Aliyah by the school environment $\left(\mathrm{X}_{1}\right)$ [18].

\section{The Effect of Teacher Work Motivation ( $\left.\mathrm{X}_{2}\right)$}

It shows that teacher job motivation has a big impact on teacher professionalism based on research results. The claim that teacher job motivation has a big impact on teacher professionalism is also supported by these results. The result of the analysis found in table 5 shows if the value of motivation for teacher work $\left(\mathrm{X}_{2}\right)$ rises unit score, so teacher professionalism $(\mathrm{Y})$ rises by 0.389 unit score so that motivation value to teacher work $\left(\mathrm{X}_{2}\right)$ is stable. Concerning the severity of a significant influence, it is shown in Figure 5 with $t_{\text {count }}$ of 3.955 with a significant level of $0.000(\mathrm{p}<0.05)$ for the acquisition of teacher work motivation $\left(\mathrm{X}_{2}\right)$, so rejecting $\mathrm{H} 0$ indicates that there is a significant influence in between motivation of teacher work $\left(\mathrm{X}_{2}\right)$ on professionalism for teachers $(\mathrm{Y})$. This shows that enthusiasm for teacher work $\left(X_{2}\right)$ affects the professionalism of teachers (Y).

Sulthoni et. al. and Marphudok et al, confirm the findings of this report, which concludes that in theory, motivation is a stimulus that occurs in the individual self either because of his consciousness or because of stimulation from outside himself to carry out something in the hope of achieving the desired goal [12] \& [5]. As an aspect of engaging in improving the standard of education, the good level of success of a teacher as an educator in schools is the justification for conducting research.

\section{The Effect of $X_{1}$ and $X_{2}$ on $Y$}

The study results clarify that the school atmosphere and support for teacher work have a major impact on teacher professionalism. These theories assert that a major influence on teacher professionalism is the school climate and the creation of teacher job motivation. This can be seen from $F$ test conducted where the count is $10.104>\mathrm{F}_{\text {table }}$ is 3.160 by taking a substantial level of $0.002(\mathrm{p}<0.05)$, then $\mathrm{H}_{0}$ is rejected and $\mathrm{Ha}$ is accepted. This ensures that it can be inferred that there is a mutual effect on teacher professionalism between school environments and teacher work motivation and suggests a positive connection between school atmosphere and motivation for teacher work on teacher professionalism. This explains that aspects of the school environment and motivation for teacher work actively impact teacher professionalism.

This is reported by the research of Wulandari which finds that there is a joint link between the school climate and the motivation for teacher work on teacher professionalism [18]. Kristiawan \& Rahmat also describe a similar opinion that teachers are part of an essential aspect of a learning process [19]. Teacher professionalism refers to a teacher's abilities and competence in pedagogical, personal, social, and professional skills. These same findings of this research are also in line with research conducted by Yuliandri which notes that teacher professionalism involves many things, including how much the teacher's mastery is in preparing and executing the duties and responsibilities of teachers in schools related to service and career, including teaching and guiding their students [20]. Discussing the learning outcomes of students, planning the requisite administration of learning, and other learning-related activities. These same findings of this research are also in line with Hafizoh et. al. research, which explains that professionalism is a motivator that will position the bureaucracy with the task's needs, It is a condition for the development of a competent apparatus, effective government media, and a measure of employees' ability to function well [20].

\section{CONCLUSION}

It can be concluded that 1) there is a significance of the school environment on the professionalism of State Junior High School teachers in Kertapati Area, Palembang; 2) the motivation to teacher work also has an impact on the professionalism of SMP Negeri teachers in Kertapati Area, Palembang; and 3) the school environment and teacher work motivation have an impact on the professionalism of State Secondary School teachers in Kertapati Area, Palembang. 


\section{REFERENCES}

[1] Elfita, R., Zulhaini., \& Ikrima, M. (2019). Pengaruh Lingkungan kerja Terhadap Kinerja Guru Pendidikan Agama Islam di MTS Negeri Sentajo Filial Singingi Kecamatan Singingi Kabupaten Kuantan Singingi. Jurnal AL-HIKMAH Vol 1, No 1. https://ejournal.uniks.ac.id/index.php/Alhikmah /article/view/84

[2] Mangkunegara, A. P. (2009). Manajemen Sumber Daya Manusia (ed. 9) Bandung: Remaja Rosdakarya.

[3] Info Publik (2019). SMP Negeri 12 Palembang,Sekolah Pinggiran Syarat Prestasi. http://infopublik.id/kategori/nusantara/388905/smp n-12-palembang-sekolah-pinggiran-sarat-prestasi.

[4] Khasanah, U., Kristiawan, M., \& Tobari. (2019). The Implementation of Principals' Academic Supervision in Improving Teachers; Professionalism in the State Primary Schools. International Journal of Scientific \& Technology Research, 8 (8). https://www.ijstr.org/paperreferences.php?ref=IJSTR-0819-21239

[5] Marphudok., Lian, B., \& Fitria, H. (2020). Pengaruh Lingkungan Kerja dan Motivasi Kerja terhadap Kinerja Guru SMA di Kecamatan Muara Padang. Jurnal Intelektualita: Keislaman, Sosial, dan Sains Vol. 9, No. 1, Juni 2020. http://jurnal.radenfatah .ac.id/index.php/intelektualita/article/view/5647

[6] Andriani, S., Kesumawati, N., \& Kristiawan, M. (2018). The Influence of the Transformational Leadership and Work Motivation on Teachers Performance. International Journal of Scientific \& Technology Research, 7(7). https://www.ijstr.org /final-print/july2018/The-Influence-Of-The-Trans formational-Leadership-And-Work-Motivation-On -Teachers-Performance.pdf

[7] Ruslan., Fitria, H., \& Lian, B. (2020). The Influence of Principal's Situational Leadership and Teacher's Professionalism on Teacher's Performance. International Journal of Progressive Sciences and Technologies (IJPSAT).135. https:/ /ijpsat.ijshtjournals.org/index.php/ijpsat/article/ view/1733

[8] Muhson, A. (2014). Meningkatkan Profesionalisme Guru: Sebuah Harapan. Jurnal Ekonomi \& Pendidikan, Vol, 2 No. 1, 2014. https:// journal.uny.ac.id/index.php/jep/article/view/665

[9] Uno, H. (2017). Teori Motivasi dan Pengukurannya Analisis di Bidang Pendidikan. Jakarta: PT Bumi Aksara.

[10] Setiyati, S. (2014). Pengaruh Kepemimpinan Kepala Sekolah, Motivasi Kerja, dan Budaya Sekolah terhadap Kinerja Guru. Jurnal Pendidikan Teknologi dan Kejuruan. Vol. 22, No. 2. 200-207. https://journal.uny.ac.id/index.php/jptk/article/vie w/8931/0

[11] Kartini, D., \& Kristiawan, M. (2019). Pengaruh Tunjangan Profesi dan Motivasi Kerja Terhadap Kinerja Guru. JMP FKIP Universitas Kristen Satya
Wacana. Volume: 6, No. 1, 2019 https://ejournal.uksw.edu/kelola/article/view /2276.

[12] Sultoni, M., Mulyadi., \& Lian, B. (2020). The Influence of School-Based Management and Work Motivation Towards Teacher's Performance. International Journal of Educational Review, Vol. 2, Issue 2, https:// ejournal.unib.ac.id/index.php/ IJER/article/view/10990

[13] Supardi, I. (2003). Lingkungan Hidup dan Kelestarianya. Bandung: PT Alumni.

[14] Yusuf, S. (2001). Psikologi Perkembangan Anak dan Remaja. Bandung: PT. Remaja Rosdakarya

[15] Sukmadinata, N. S. (2004). Metode Penelitan Tindakan. Bandung: PT Remaja Rosdakarya.

[16] Hadi, S. (2000). Metodologi Research Jilid I. Yogyakarta: Andi Offset.

[17] Sugiyono. (2015). Metode Penelitian Kuantitatif, Kualitatif, dan R\&D. Bandung: Alfabeta.

[18] Wulandari, Y. (2018). Pengaruh Lingkungan Sekolah dan Motivasi Kerja terhadap Profesionalisme Guru Madrasah Aliyah SeKecamatan Kalianda Lampung Selatan. IAIN Metro. Lampung.

[19] Kristiawan, M., \& Rahmat, N. (2018). Peningkatan Profesionalisme Guru Melalui Inovasi Pembelajaran. Jurnal Iqra': Kajian Ilmu Pendidikan. Volume 3, Issue 2, December 2018. Hal. 373-390. https://journal.iaimnumetro lampung .ac.id/index.php/ji/article/view/348

[20] Yuliandri, J. (2018). Pengaruh Kepemimpinan Kepala Sekolah dan Budaya Organisasi Sekolah Terhadap Profesionalisme Guru. (Tesis). Program S2 Manajemen Pendidikan. Universitas PGRI Palembang

[21] Hapizoh. Harapan, E., \& Destiniar. (2020). Pengaruh Profesionalisme Guru dan Supervisi Kepala Sekolah terhadap Kinerja Guru. JMKSP. Volume 5, No 2, Juli-Desember 2020. https://jurnal.univpgri-palembang.ac.id/index. php/JMKSP/article/view/3764 